\title{
Growth performance and immune response of Labeo rohita under the dietary supplementation of black seed (Nigella sativa)
}

\author{
Asad Ali", Nudrat Aslam, Jawairia Bashir, Muhammad Naveed, Ali \\ Raza and Hamza Rehman \\ Department of Zoology, Wildlife and Fisheries, University of Agriculture, Faisalabad-Pakistan \\ *Corresponding author's email: animaldiversity22@gmail.com \\ Citation \\ Asad Ali, Nudrat Aslam, Jawairia Bashir, Muhammad Naveed, Ali Raza and Hamza Rehman. Growth \\ performance and immune response of Labeo rohita under the dietary supplementation of black seed (Nigella \\ sativa). Pure and Applied Biology. Vol. 9, Issue 4, pp2339-2346. http://dx.doi.org/10.19045/bspab.2020.90248
}

\begin{tabular}{|c|c|c|c|}
\hline Received: 11/03/2020 & Revised: $16 / 06 / 2020$ & Accepted: 24/06/2020 & Online First: 08/07/2020 \\
\hline
\end{tabular}

\section{Abstract}

Black seed (Nigella sativa) is used as a natural immuno-stimulant in the feed of various farmed animals. In this study, the effect of three dietary inclusion levels of $N$. sativa was assessed on growth performance and immune response of Labeo rohita for 8 weeks. Growth parameters in terms of weight $(\mathrm{g})$, length $(\mathrm{cm})$, feed conversion ratio and specific growth rate (SGR) along with immunity response parameters including white blood cells, lysozyme activity, and globulins protein were measured in this study. All the recorded growth and immunity parameters showed a significantly different outcome at the end of the experimental trial. The group fed by $4 \%$ black seed showed the highest increase in weight gain $(14.20 \pm 0.621 \mathrm{~g})$ increase in length $(2.26 \pm 0.11 \mathrm{~cm})$ specific growth rate $(1.34 \pm 0.45)$ and best value of feed conversion ratio $(2.27 \pm 0.56)$ followed by $3 \%$ and $2 \%$. Among the immunity parameters, group of fish fed by $4 \%$ black seed in the diet showed an increase in white blood cell count $\left(19810^{3} / \mu \mathrm{L} \pm 3.78\right)$, globulin protein $(23.66 \mathrm{mg} / \mathrm{dl}$ $\pm 1.21)$ and lysozyme activity $(60.66 \mu 1 / \mathrm{ml} \pm 1.20)$ followed by $3 \%$ and $2 \%$. Inferences of this study reveal that $N$. sativa improves the growth and immunity of $L$. rohita.

Keywords: Globulin; Length; Lysozyme activity; Weight; White blood cells

\section{Introduction}

The aquaculture industry has very commercial significance as it is a great source of earning that contribute into the economy of the country along with providing the essential nutrients to human. However, the growth and weight are the main points of interest [1] for which a perfect diet supplemented with all the essential nutrients is mandatory to give maximum growth and weight to fish [2]. Feed conversion ratio is primarily required to maximize fish growth and weight gain [3]. To increase economically viable production without affecting the growth and overall health of fish, proper herbal feed supplementation is a prerequisite to endure environmental fluctuations [4]. Using a feed supplement for the improvement of fish growth and health has attained widespread interest and appreciation [5].

Immuno-stimulants increase both the specific and non-specific immunity by enhancing the resistance to disease [6]. A lot of ways are used by these immunostimulants to enhance non-specific immunity parameters by increasing 
complement and Immunoglobulin M (IgM) levels, the activity of natural killer, and phagocytic activity. The immunostimulants directly involved in the initiation of the innate immune system that acts on receptors and starts the activation of intracellular genes which result in the formation of antimicrobial particles [7]. The use of plants and their extracts is becoming more popular than chemical products. Therapeutic plants have been utilized in customary frameworks to treat numerous infections [8]. Biologically active substances of plant sources are a part of animal feed that effects the feed conversion ratio, growth activity of digestive enzymes, and immune system [9]. Black seed ( $N$. sativa) is a member of family Ranunculaceae, which showed fungicidal and anti-bacterial effects in animals [10]. $N$. sativa has been used for improvement in growth and immune mechanism of several species of fish [11, 12]. The oil and the derivatives of black cumin has a significant role as antioxidant, anti-inflammatory, anticancer, analgesic and antimicrobial activities [13].

Among Indian major carps, $L$. rohita consider a good basis of protein and has beneficial status as commercial fish [14]. L. rohita is mostly used in polyculture [15]. It has maximum acceptability as a source of food for purchasers due to its good flesh and taste. It has maximum market need in term of food in Asia [16]. Because of the above reasons, we select $L$. rohita for research to achieve better outcomes in terms of per capita production.

In research, we use $N$. sativa in feed to check its effect on the growth and immunity of L. rohita.

\section{Materials and methods Experimental design}

A total of 120 fishes of L. rohita (Rohu) having initial weight $15.48 \pm 0.11 \mathrm{~g}$ (mean \pm $\mathrm{SD})$ were divided into four triplicate groups (each replicate contained 10 fish). Before the start of the trial, L. rohita fingerlings in glass aquarium were acclimatized to laboratory conditions for one week in tanks. During this period, fish were fed by basal feed. Aquaria were provided by aerators to supply proper oxygen. DO and water temperatures were checked daily. $\mathrm{pH}$ was measured by electronic $\mathrm{pH}$ meter weekly.

\section{Feed preparation}

Basal fish feed constituents contained soya bean meal, fish meal, wheat flour, rice polish, minerals, vitamins and sunflower oil. All the ingredients were grounded in mortar and pestle to get in the powder form. Black seed was obtained from the local market and dried it for 3 days and then ground by pestle and mortar in a powder form (Table 1) The experimental feed was prepared by adding black seed powder in a basal diet in the proportion of $2 \%, 3 \%$ and $4 \%$. The control group feed was without black seed. Feed was given a rate of 3\% body weight of fish for eight weeks of the experiment.

Table 1. Basal feed preparation ingredients

\begin{tabular}{|c|c|}
\hline Ingredients & Weight (g) \\
\hline Fish meal & 45 \\
\hline Soya bean meal & 35 \\
\hline Rice polish & 4 \\
\hline Wheat flour & 6 \\
\hline Mineral and vitamins & 4 \\
\hline Sunflower oil & 6 \\
\hline Total & 100 \\
\hline
\end{tabular}

\section{Growth and immunity parameters}

Fish weight (g), length $(\mathrm{cm})$ Feed conversion ratio (FCR) and specific growth rate (SGR) were measured weekly. After completing the 08 weeks of the experiment, the immune parameters were determined 
from blood samples obtained from the caudal vein of fish and separated into two parts. One was used for the count of white blood cells. The second part was kept overnight at $4^{\circ} \mathrm{C}$ for clot formation. It was used then for serum collection. Heamocytometer was utilized for the count of WBCs. "Total protein" and "albumin" kits were used for the measurement of the levels of total proteins and albumins in serum respectively. After that by directing subtracting the values of albumin from that of total protein, the level of globulins was calculated. For the measurement of lysozyme activity of serum, a specific kit known as LZM test kit (Nanjing Jiancheng Bioengineering Institute, China) [17].

\section{Statistical analysis}

Data obtained after calculation of growth and immunological parameters were subjected to statistical analysis by using Minitab 18.0 statistical software. One-way ANOVA was used for the analysis of data. Tukey's pairwise multiple comparison tests were used to check differences among the treatments.

\section{Results and discussion}

Results of the research were indicated that black seed supplemented feed affected the growth and immunity of fish.

\section{Growth parameters}

Description of growth are shown in (Table 2). The final weight was maximum in fish that fed by diet with $4 \% N$. sativa which was $29.80 \pm 0.64 \mathrm{~g}$. This showed that $N$. sativa containing feed has a productive effect on the growth of fish. The final length was also indicated a significant difference among treatments $(\mathrm{p}<0.05)$. The final length was showed a maximum in fish of $4 \%$ black seed group followed by $3 \%$ and then $2 \%$.

Feed conversion ratio is increased by adding new ingredients in the feed that give better growth [3]. Feed conversion ratio also remained efficient in the group of fish treated with $4 \%$ black seed.

Table 2. Statistically demonstration at the end of trial; Average gain in wet weight $(\mathrm{g} \pm \mathrm{SD})$, average increase in length $(\mathrm{cm} \pm \mathrm{SD})$, feed conversion ratio and specific growth rate

\begin{tabular}{|c|c|c|c|c|}
\hline & $\mathbf{0 \%}($ Control) & $\mathbf{2 \%}$ & $\mathbf{3 \%}$ & $\mathbf{4 \%}$ \\
\hline Initial average weight $(\mathrm{g})$ & $15.54 \pm 1.34$ & $15.34 \pm 1.25$ & $15.45 \pm 0.86$ & $15.60 \pm 0.76$ \\
\hline Final average weight $(\mathrm{g})$ & $22.28 \pm 0.64^{\mathrm{d}}$ & $23.86 \pm 0.56^{\mathrm{c}}$ & $26.86 \pm 0.67^{\mathrm{b}}$ & $29.80 \pm 0.64^{\mathrm{a}}$ \\
\hline Average Weight gain $(\mathrm{g})$ & $6.74 \pm 0.415^{\mathrm{d}}$ & $8.52 \pm 0.388^{\mathrm{c}}$ & $11.41 \pm 0.327^{\mathrm{b}}$ & $14.20 \pm 0.621^{\mathrm{a}}$ \\
\hline Initial average length $(\mathrm{cm})$ & $10.80 \pm 1.07$ & $10.85 \pm 1.14$ & $10.82 \pm 1.08$ & $10.86 \pm 1.12$ \\
\hline Final average length $(\mathrm{cm})$ & $11.57 \pm 0.66^{\mathrm{b}}$ & $12.21 \pm 1.29^{\mathrm{ab}}$ & $12.32 \pm 1.11^{\mathrm{ab}}$ & $13.12 \pm 0.57^{\mathrm{a}}$ \\
\hline Average gain in length $(\mathrm{cm})$ & $0.77 \pm 0.06^{\mathrm{d}}$ & $1.36 \pm 0.06^{\mathrm{c}}$ & $1.50 \pm 0.09^{\mathrm{b}}$ & $2.26 \pm 0.11^{\mathrm{a}}$ \\
\hline Feed conversion ratio & $4.07 \pm 0.80^{\mathrm{a}}$ & $3.38 \pm 0.82^{\mathrm{ab}}$ & $3.01 \pm 1.86^{\mathrm{ab}}$ & $2.27 \pm 0.56^{\mathrm{b}}$ \\
\hline Specific growth rate & $0.73 \pm 0.15^{\mathrm{b}}$ & $0.89 \pm 0.19^{\mathrm{ab}}$ & $1.12 \pm 0.50^{\mathrm{ab}}$ & $1.34 \pm 0.45^{\mathrm{a}}$ \\
\hline
\end{tabular}

The specific growth rate showed significantly different values for black seed supplemented groups as compared to the control group $(p<0.05)$. It revealed maximum values for a group of fish treated with $4 \%$ black seed followed by $3 \%$ then $2 \%$. These results resembled Wafaa et al. [18] who estimated the effects of the extracts of green tea, propolis and black seed on the body composition, growth \& the economic competence of the $O$. niloticus. Their results revealed that the weight gain (g), FCR and final body mass notably rise in the groups which were fed with the black seed.

Data were demonstrated as mean \pm SD. Within the same row different superscripts, letters show statistically different results ( $p$ $<0.05)$.

The gain in weight was showed a significant difference among black seed supplemented treatments $(\mathrm{p}<0.05)$. The maximum gain in weight was $14.20 \pm 0.621$ in $4 \%$ black seed treated group followed by $11.41 \pm 0.327$ in $3 \%$ and then $8.52 \pm 0.388$ in $2 \%$. 
The final length was also indicated a significant difference among treatments $(p<0.05)$. The final gain in length was showed a maximum $2.26 \pm 0.11$ in fish of $4 \%$ black seed group followed by $3 \%$ and then $2 \%$. Feed conversion ratio remained efficient in the group of fish treated with $4 \%$ black seed.

The finding has resemblance with $\mathrm{Oz}$ et al. [19] who estimated the growth performance and fatty acid composition of rainbow trout enhanced under the influence of black seed as a feed additive. The fish flourish well on feed artificially made or a productive converter of various types of foodstuff [20]. Using artificial feed in farming fish achieved good weight [2] increases fish activity and growth in limited time [21]. $N$. sativa has been used for improvement in growth and immune mechanism of several species of fish [22]. It is also recognized as the growth promotor for fish [23-25]. The response of $N$. sativa on the digestive system, showing betterment for absorption and performance, enhanced bile flow rate results in an increase of emulsification action which activated the enzymes like lipases, necessary for absorption and digestion of fat and fat-soluble vitamins [26].

\section{Immunity parameters}

Immunostimulants can increase specific and non-specific immunity by increasing the resistance for disease [27]. Oil of black seed have properties of immunostimulant and immunomodulatory $[28,29]$. There is an increased of resistance in fishes for infectious disease using immunostimulants which regulate acquired immunity as well as innate immunity [30]. Fish received black seed revealed the highest increase in immunity parameters like white blood cell count, globulins proteins and lysozyme activity White blood cells are the base of the defense system in the body and play a significant role to keep the organism immune to external attacks [31].

In the present study, the average White blood cells were significantly higher in black seed supplemented groups. 4\% showed higher values for white blood cell count than others (Fig. 1). The fish group supplemented by $4 \%$ black seed showed higher values for globulins than other supplemented groups (Fig. 2). The addition of plant originated immunostimulants in the diet of $L$. rohita resulted in an increased level of serum lysozymes. Black seed supplemented groups showed higher lysozyme activity as compared to control (Fig. 3).

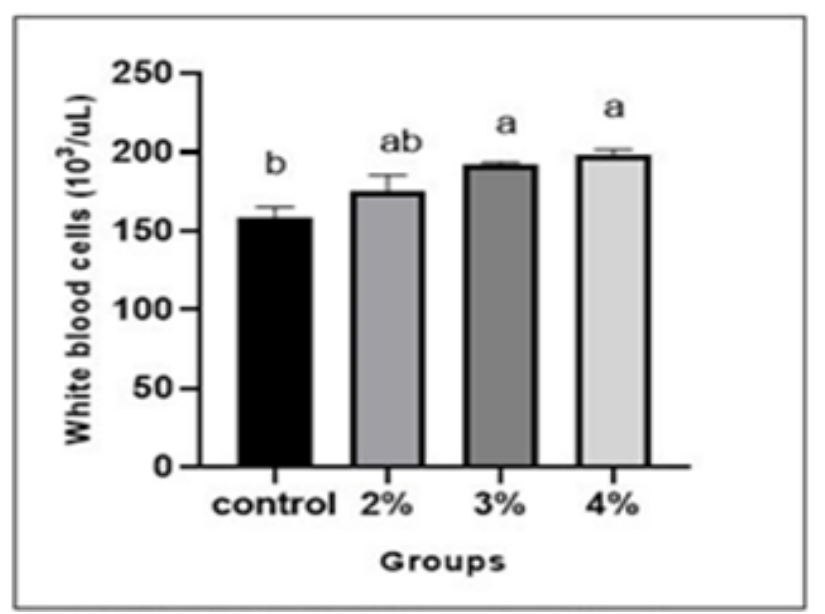

Figure 1. White blood cells of Labeo rohita fed by feed supplemented by $0 \%, 2 \%, 3 \%$ and 4\% black sedd. Different superscript letters show statistical different results $(\mathbf{p}<0.05)$. Bars $=$ mean + SD 


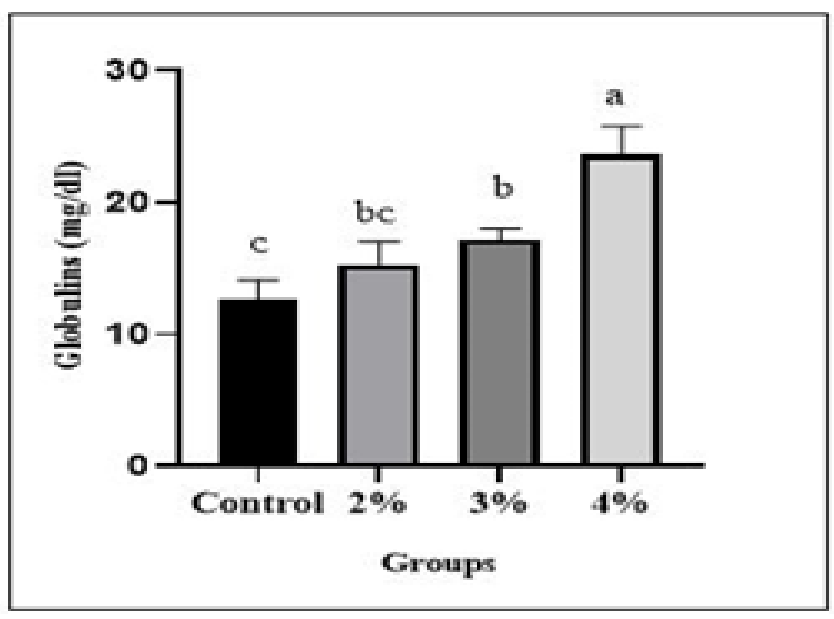

Figure 2. Globulins protein (mg/dl) of Labeo rohita fed by feed supplemented by $0 \%, 2 \%$, $3 \%$ and $4 \%$ black sedd. Different superscript letters show statistical different results $(p<$ 0.05). Bars $=$ mean + SD

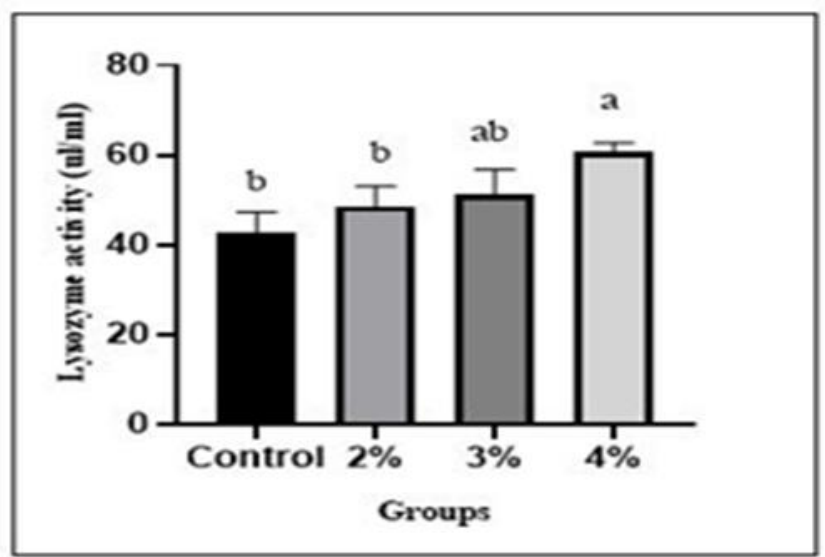

Figure 3. Lysozyme activity (ul/ml) of Labeo rohita fed by feed supplemented by $0 \%, 2 \%$, $3 \%$ and $4 \%$ black sedd. Different superscript letters show statistical different results $(\mathrm{p}<$ 0.05). Bars= mean+SD.

Sahu et al. [32] revealed that there was present a large numbers of WBCs in $L$. rohita fingerlings which were fed by diet mixed with herbal ingredients. This increased level of WBCs indicated the improvement of the non-specific immune system of fishes. Higher values of white blood cells in fish showed that black seed has an effective result. $N$. sativa extract has a beneficial impact on leukocytes production [33]. Altinterim and Dorucu [34] investigated the fluctuations in a few specific immune parameters of Oncorynchus mykiss by using feed with $N$. sativa seeds. The hematological parameters including immunity parameters were improved in N. sativa treated groups. The same results were reported by Dorucu et al. [35] who concluded that the incorporation of different percentages of black seed in the basic diet of rainbow trout notably increase the immunoglobulins Lysozyme is a constituent of non-specific immune system [36]. Lysozyme count was higher in fish supplemented by $4 \%$ black seed. The current study was supported by the results of Chen et al. [37] who reported that the activity of plasma lysozyme in crucian carp was enhanced by using herbal feed additives.

\section{Conclusion}

It is observed that feed containing $N$. sativa is suitable to enhance the growth and immunity parameters of fish. The result 
showed that feed having the highest percentage of $N$. sativa has productive outcomes for gaining weight and the size of fish. It is also effective for the white blood cells, globulins proteins and lysozyme activity enhancement to achieve better resistance against disease.

\section{Authors' contributions}

Conceived and designed the experiments: A Ali \& J Bashir, Performed the experiment: M Naveed \& A Raza, Analyzed the data: H Rehman \& N Aslam, Contributed regents/materials/analysis tools: H Rehman \& M Naveed, Wrote the paper A Ali \& N Aslam.

\section{Acknowledgments}

We thankfully acknowledge the University of Agriculture, Faisalabad, Pakistan, for the provision of experimental tools, environment for making research effective and financial assistance for purchasing necessary things and feed for fish.

\section{References}

1. Schuchardt D, Vergara JM, Palaciso HF, Kalinowski CT, Cruz CM, Izquierdo MS \& Robaina L (2008). Effects of different dietary protein and lipid levels on growth, feed utilization and body composition of red porgy (Pagrus pagrus) fingerlings. Aquacult Nutr 14: 1-9.

2. Bhosale SV, Bhilave MP \& Nadaf SB (2010). Formulation of fish feed using ingredients from plant sources. Res $J$ Agric Sci 1: 284-287.

3. Fernandez-Navarro M, Peragon J, Esteban F, Higuera M \& Lupianez JA (2006). Maslinic acid as a feed additive to stimulate growth and hepatic protein turnover rates in rainbow trout (Onchorhynchus mykiss). Comp Biochem Physiol C Toxicol Pharmacol 144: 130-140.

4. Shakya SR (2017). Effect of herbs and herbal products feed supplements on growth in fishes: A review. Nepal $J$ Biotechnol 5: 58-63.

5. Higuera M \& Lupianez JA (2006). Maslinic acid as a feed additive to stimulate growth and hepatic proteinturnover rates in rainbow trout (Onchorhynchus mykiss). Comp Biochem Physiol C Toxicol Pharmacol 144: 130-140.

6. Chakrabarti R, Das BK, Jyotyrmayee P \& Rao YV (2006). Effect of Achyranthes aspera on the immunity and survival of Labeo rohita infected with Aeromonas hydrophila. Fish Shellfish Immunol 20: 263-273.

7. Bricknell I \& Dalmo RA (2005). The use of immunostimulants in fish larval aquaculture. Fish Shellfish Immunol 19: 457-472.

8. Magi E \& Sahk M (2003). Use of herbal medicine principle in local conditions. Agraarteadus 14: 172-178.

9. Shalaby SM (2004). Response of Nile tilapia, Oreochromis niloticus, fingerlings to diets supplemented with different levels of fenugreek seeds (Hulba). J Agric Mansoura Univ 29: 2231-2242.

10. Akgul A (1989). Antimicrobial activity of black cumin (Nigella sativa L.) essential oil. Gazi J Fac Pharm 6: 6368.

11. Abdel-Ghaffar FA, El-Feki MA, Faheem HI \& Gad MA (2003). Potentiating effects of some natural products on the common carp immune system against Pseudomonas florescence. Egypt J Aquat Biol Fish 7: 23-47.

12. Diab AS, Aly SM, John G, Abde-Hadi Y \& Mohammed MF (2008). Effect of garlic, black seed and Biogen as immunostimulants on the growth and survival of Nile tilapia, Oreochromis niloticus (Teleostei: Cichlidae), and their response to artificial infection with Pseudomonas fluorescens. Afr J Aquat Sci 33: 63-68.

13. Gali-Muhtasib H, El-Najjar N \& Schneider-Stock R (2006). The medicinal potential of black seed (Nigella sativa) and its components. Adv Phytomedicine 2: 133-153.

14. Rahman AA (2005). Freshwater fishes of Bangladesh. ZSB pp 110-124. 
15. Umer K \& M Ali (2009). Replacement of fishmeal with blend of canola meal and corn gluten meal, and an attempt to find alternate source of milk fat for rohu (Labeo rohita). Pak J Zool 4: 469-474.

16. Boonthai T, Vuthhiphandchai V \& Nimrat S (2011). Probiotic bacteria effects on growth and bacterial composition of black tiger shrimp (Penaeus monodon). Aquacult Nutr 17: 634-644.

17. Dan X, Zhang T, Li Y \& Li A (2013). lmmune responses and immune-related gene expression profile in orangespotted grouper after immunization with Cryptocar yon irritans vaccine. Fish Shellfish Immunol 34: 885-891.

18. Wafaa E, Doaa I, El-Murr A \& Rania M (2014). Effects of dietary inclusion of black cumin seeds, green tea and propolis extraction on growth parameters, body composition and economic efficiency of Nile tilapia, Oreochromis niloticus. World J Fish Mar Sci 6: 447-452.

19. Oz Dikel MS \& Durmus M (2018). Effect of black cumin oil (Nigella sativa) on the growth performance, body composition and fatty acid profile of rainbow trout (Oncorhynchus mykiss). Iran J Fish Sci 17: 713-724.

20. Omoregie E, Igoche L, Ojobe TO, Absalom KV and Onusiriuka KV (2009). Effect of varying levels of sweet potato (Ipomea batatas) peels on growth, feed utilization and some biochemical responses of the cichlid (Oreochromis niloticus). Afri J Food Agri Nutr Dev 9: 700-712.

21. Al-Dubakel AY, Al-Mhawe BH, Majeed MF \& Shaeyal LW (2012). Preliminary study on the effect of dietary black seed (Nigella sativa) on growth and blood glucose of common carp (Cyprinus carpio) fingerlings. ThiQar Uni J Agric Res 2: 41-51.

22. Diab AM, Salem RM, El-Keredy, Abeerc MS, Gehan, Alic IE \& ElHabashid N (2018). Experimental ochratoxicosis $\mathrm{A}$ in Nile tilapia and its amelioration by some feed additives. Int J Vet Sci Med 6: 149-158.

23. Burits M \& Bucar F (2000). Antioxidant activity of Nigella sativa essential oil. Phyt Res 14: 323-328.

24. Khattab YA (2001). Effect of substituting black seed cake (Nigella sativa) for soybean meal in diets of nile Tilapia. (Oreochromis niloticus L.) on growth performance and nutrients utilization. Egypt J Aquat Biol Fish 2: 31- 46.

25. John G, Salah M, Mahmoud R, Gamal E \& Mohamed F (2007). Effect of some immunostimulants as feed additives on the survival and growth performance of Nile tilapia, Oreochromis niloticus and their response to artificial infection. Egypt J Aquat Biol Fish 11: 1299 -1308.

26. Jamroz D \& Kamel C (2002). Plant extracts enhance broiler performance. In non-ruminant nutrition; antimicrobial agents and plant extracts on immunity, health and performance. $J$ Anim Sci 80: 41.

27. Chakrabarti R \& Rao YV (2006). Achyranthes aspera stimulates the immunity and enhances the antigen clearance in Catla catla. Int Immunopharmacol 6: 782-790.

28. Badary OA \& Gamal AM (2001). Inhibitory effects of thymoquinone against 20- methylcholantherene induced fibrosarcoma tumorigenesis. Cancer Detect Prev 25: 362-368.

29. Islam NSK, Begum $P$, Ahsan T, Huque $S \quad \&$ Ahsan M (2004). Immunosuppressive and Cytotoxic Properties of Nigella sativa. Phytother Res 18: 395-398.

30. Dugenci, SK, Arda N \& Candan A (2003). Some medicinal plants as immunostimulant for fish. $J$ Ethnopharmacol 88: 99-106.

31. Whyte SK (2007). The innate immune response of finfish-a review of current knowledge. Fish Shellfish Immunol 23: 1127-1151.

32. Sahu S, Das BK, Pradhan J, Mohapatra BC, Mishra BK \& Sarangi N (2007). 
Effect of Magnifera indica kernel as a feed additive on immunity and resistance to Aeromonas hydrophila in Labeo rohita fingerlings. Fish Shellfish Immunol 23: 109-118.

33. Mona Z, Rakha G, Osfor M, Bayumi F $\&$ Saad M (2002). Some clinicpathological and microbiological changes with hypercholestrimia in sheep and a trial of treatment with Nigella sativa and Titanium ascorbate. Bull NRC Egypt.

34. Altinterim, B \& Dorucu M (2013). The Effects of Nigella sativa oil on the immune system of rainbow trout with different applications methods. J Fish Sci 7: 209-215.
35. Dorucu M, Colak SO, Ispir U, Altinterim B \& Celayir Y (2009). The effect of black cumin seeds, Nigella sativa, on the immune response of rainbow trout, Oncorhynchus mykiss. Mediterr Aquacult J 2: 27-33.

36. Ardo L, Yin G, Xu P, Varadi L, Szigeti, Jeney Z \& Jeney $G$ (2008). Chinese herbs (Astragalus membranaceus and Lonicera japonica) and boron enhance the non-specific immune response Nile tilapia (Oreochromis niloticus) and resistance against Aeromonas hydrophila. Aquacult 275: 26-33.

37. Chen X, Wu Z, Yin J \& Li L (2003). Effects of four species of herbs on immune function of Carassius auratus gibelio. J Fish Sci China 10: 36-40. 